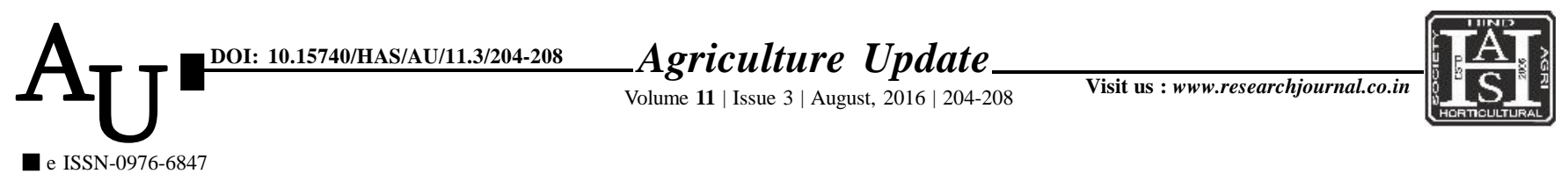

\title{
Research Article: Impact of women self-help groups (SHGs) on income, employment, investment and saving in south Konkan region
}

Article Chronicle:

Received :

03.05.2016;

Revised :

09.06.2016;

Accepted :

22.06.2016

KEY WoRds:

Impact, Income, Employment, Saving, Investment
Author for correspondence :

\section{M.G. LAGARE}

Department of Agricultural Economics, Dr. B.S. Konkan Krishi Vidyapeeth, Dapoli, RATNAGIRI (M.S.) INDIA Email : manisha.legare@ rediffmail.com

See end of the article for authors' affiliations
SUMMARY : The present study entitled, "Impact of women self help groups on income, employment, investment and saving in South konkan Region" was carried out in South Konkan region purposively. From Ratangiri district Dapoli, Khed and Guhaghar while from Sindhudurg district Kudal, Devgad and Kankavali tahsils were selected. From each tahsil, ten SHGs and five members of each SHG were selected randomly. Thus, final sample consisted of 60 SHGs, 300 SHG members. The selected SHGs were categorized taking into consideration group activities performed by SHG. The SHGs were classified as farming activities, agro-processing activities, and non-farming activities. This indicated that after joining the SHG, per member income increased to the extent of 13.87 per cent. This increase in income was 14.84 per cent in farming, 12.31 per cent in agro-processing and 14.63 per cent in non-farming category. Within different categories of groups, the increase in employment was 83.18 per cent in farming category, 61.95 per cent in agro-processing category and 77.41 per cent in non-farming category. The investment in different assets increased to the extent of 22.62 per cent after participation in SHG group. Within different categories of groups, the increase in investment was 22.22 per cent in farming category, 16.83 per cent in agro-processing category and 26.82 per cent in non-farming category. After participation in SHG activities per member saving increased by 27.84 per cent.

How to cite this article : Lagare, M.G., Talathi, J.M., Deorukhakar, A.C. and Naik, V.G. (2016). Impact of women self-help groups (SHGs) on income, employment, investment and saving in south Konkan region. Agric. Update, 11(3): 204-208, DOI : 10.15740/HAS/AU/11.3/204-208. 